\title{
Learning to Recycle Isn't Enough
}

\author{
Youth-Led Climate Activism and Climate Change Education in the UK
}

\author{
Richa Sharma
}

\begin{abstract}
Where political action on climate change is failing, young people have taken charge by organizing themselves into social movements on climate change, using protests, education campaigns, digital strikes, and other innovative media to relay their messages to policymakers. What are these messages, and what implication does this activism have for formal school education? Using the case study of the UK Student Climate Network (UKSCN), this chapter attempts to unpack the discourse on youth-led climate action to highlight key themes that young people are calling for in their formal education. Detailing activists' experiences of climate education in school, this chapter identifies three key issues in formal climate change education: (a) climate education is scarce and siloed; (b) the "commoditized" nature of learning "individualizes" issues for students and induces eco-anxiety; and (c) engagement with climate (in)justice is lacking. Analysis of interviews with youth activists and of UKSCN's campaigns on social media uncovers implications for education policy and practices. The intersectionality practiced by young people in their climate activism is a cry for intersectionality in education that must be addressed through phenomena-based learning for climate change, engaging with climate justice, teacher education, and further climate change education research centering on the perspectives and voices of the youth.
\end{abstract}

\section{Keywords}

climate change education - education for sustainable development - youth activism climate activism - UKSCN - climate justice

\section{Introduction}

They skip school on Fridays to demand action. They combine strategies old and new, sometimes staging "die-ins" outside public places, at other times

(C) UNESCO IBE, 2021 | DOI: 10.1163/9789004471818_009

This is an open access chapter distributed under the terms of the CC BY 4.0 License. 
shouting slogans at the top of their voices. While Greta Thunberg's name might be the most renowned, countless others join the movement every day. When it comes to the existential threat of climate change, mercilessly passed on to them, Gen $\mathrm{Z}$ does not sit silent.

Being a "climate activist" is intrinsic to many young people's identities. Youth mobilization on climate change today continues to influence the political, economic, and educational discourse. The UN COP25 climate summit served as a case in point. There, youth activists from across the world occupied the main stage to demand a more ambitious plan for the climate crisis (Germanos, 2019).

While there exists research analyzing the rise of youth-led climate activism (see Byrne \& Mullally, 2016; Davies et al., 2014; Fisher, 2016; Ho, 2010; Holmberg \& Alvinius, 2020; O'Brien et al., 2018; Sukarieh et al., 2014), an educational perspective remains missing from the discussions. And even fewer scholars have tried to understand the potential crossovers from youth activism to climate education (Cutter-Mackenzie \& Rousell, 2019). As is visible in Figure 8.1, climate activism by young people encompasses issues that transcend the definitional boundaries of climate change. This chapter explores the discourse characteristic of young climate activists between the ages of 15 and 18 in the UK to understand its significance and its relation to climate education.

The chapter takes as its starting point two interlinked roadblocks to quality climate change education identified by Kwauk (2020). The first roadblock is that the global education community lacks a radical vision for education (p. 9). As highlighted by Kwauk (2020) and others (Huckle \& Wals, 2015; Jucker, 2004), education for sustainable development (ESD) has failed to deliver the transformational education promised. Instead, as argued by Selby and Kagawa (2010, p. 37), ESD appears as the newest manifestation of the "closing circle" of environmental education - closed to any critical transformations as the field continues to be permeated by "highly questionable" global agendas. While the idea of "equity" is seemingly embedded in ESD, evident in the UN Sustainable Development Goals' pledge of "leaving no one behind", ESD suffers from a "design flaw", in that the notion of equity it endorses falls within the dominant paradigm of neoliberalism and therefore falls seriously short (Sharma, 2020).

The second, related, roadblock is that ESD has a problem of definition and scope (see Kwauk, 2020, p. 10). Given the openness, "unproblematized equivalence", and ambiguity around its definition, ESD has provided leeway for international organizations to influence educational agendas under their highly neoliberal narrative termed "sustainable development" (Bonnett, 1999; González-Gaudiano, 2005; Jucker, 2004).

The implications of this neoliberal version of ESD are explored in this chapter through the perspectives of young people who identify as climate activists. 


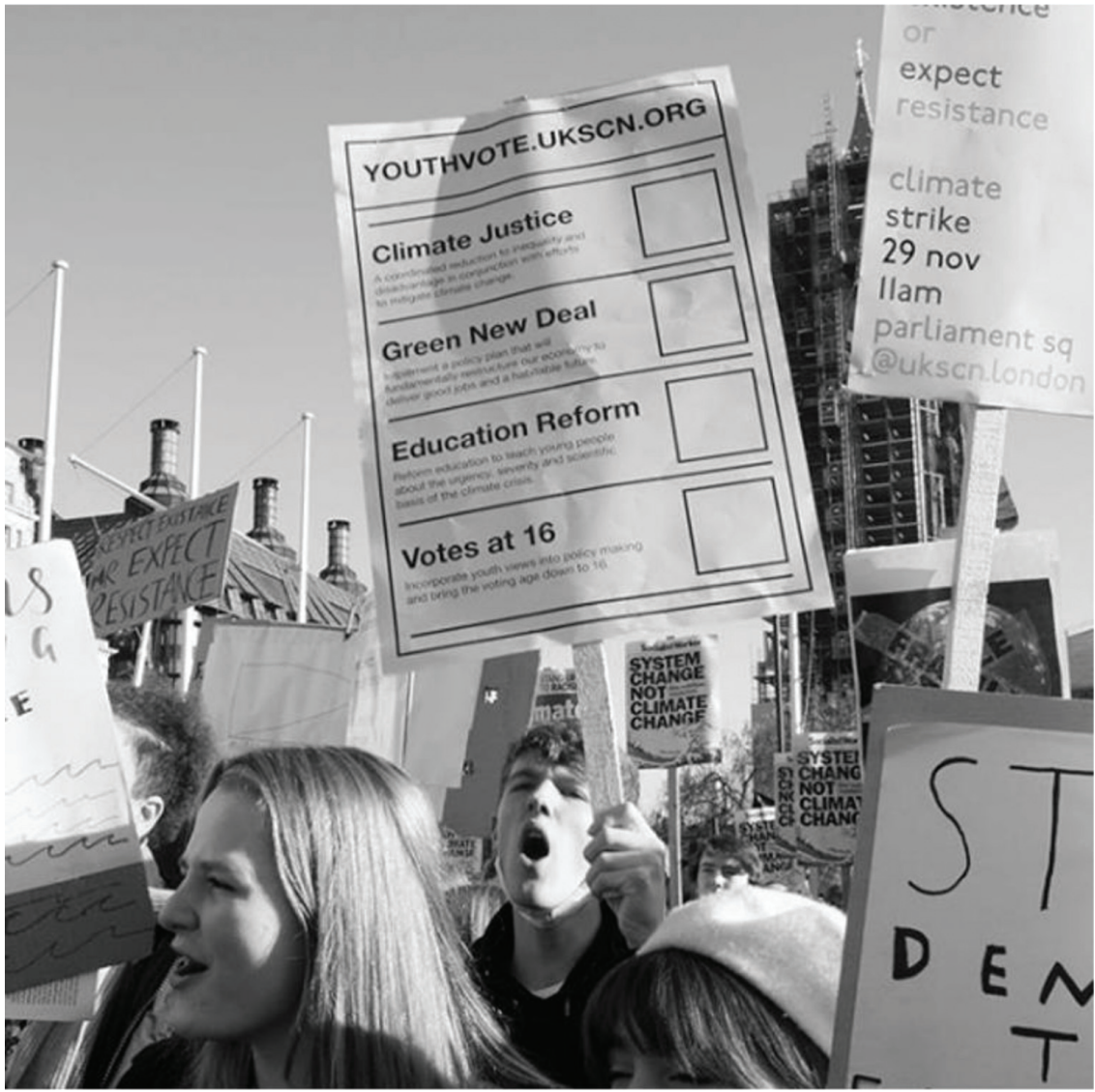

FIGURE 8.1 Youth climate activists at a protest in the UK. Source: U KSCN Instagram page, https://www.instagram.com/p/B555b6mnAcz/

I explore how the "marketization" of education, and neoliberal "responsibilization" and "individualization" have restricted and siloed young people's opportunities to engage with climate change, an approach that has not only frustrated learners but has also led to them to experience eco-anxiety. I first showcase how those who undertake youth-led climate activism are practicing a form of education that deserves to be acknowledged, because social movements provide alternate spaces in which to generate knowledge and build networks. Next, I share youth activists' school experiences of climate change education to identify the key drawbacks of, and frustrations with, the curriculum. Then I discuss how youth activists navigate the contested terrains of climate justice both inside classrooms and in activist spaces outside classrooms, before concluding with implications for the educational community. 
I collected the data I present in this chapter between April and June 2020 for research for my MPhil dissertation. I used virtual ethnography, social media analysis, and extended semi-structured interviews with five climate activists between the ages of 15 and 18 from the UK Student Climate Network (UKSCN) (whom I thank here for their invaluable contributions to this research).

\section{Youth-Led Climate Activism and Climate Change Education: What Are the Links?}

Through their work with young people in the Climate Change and Me project in the Australian context, Cutter-Mackenzie and Rousell (2019) highlight the need to appreciate young people as co-researchers and legitimate contributors to educational research and practice. They also recognize a crucial lacuna in environmental research: the lack of crossover from environmental activism being undertaken by young people to environmental education. The cause of this lacuna is the lack of appreciation of alternate spaces outside the school environment as spaces of learning and of generating new knowledge. Learning occurs in multiple forms, and it is least acknowledged in the informal form it takes in social movements, of which children and youth are increasingly a part. Methodological treatment of children's learning through engagement in social and political mobilization on climate change is in its nascent stage and deserves greater attention.

As noted by Choudry (2015, p. 167), although some social movements are expressed creatively, often using arts-based methods,

the ways in which some "alternative" spaces replicate the very structures of economic and political power that they exist to struggle against has had major impacts on what - and whose - learning and knowledge is valued.

It is imperative that research on ESD and climate change education take into account that learning is not confined to schools and that it pays heed to informal spaces of building knowledge and networks.

Clover and Hall (2010) concur: "Of all our cognitive capacities, the imagination is the one that permits us to give credence to alternative realities" (p. 164). They define "social movement learning" as both (a) "learning by persons who are part of any social movement"; and (b) "learning by persons outside of a social movement as a result of the actions taken or simply by the existence 
of social movements" (p. 164). This way of thinking broadens the meaning of ESD - and education more generally - by taking into account non-formal and informal learning.

Clover and Hall (2010) not only recognize that these types of learning often take place outside the premises of formal learning institutions, such as schools, but they also formalize the role social movements play in education. They further subdivide categories of non-formal learning. They distinguish learning that occurs through social movements, which they call intentional, from informal learning, which they call incidental (p. 164). An example of a social movement's intentionally organized educational activities: the Australian Youth Climate Coalition operates a program called Switched On Schools, running workshops, trainings, and leadership programs in high schools to interest students in climate justice and to initiate climate action in schools. ${ }^{1}$ Similar endeavors occur elsewhere on a voluntary, student-led basis as part of student clubs or such activities as Model United Nations. The other kind of non-school learning, "incidental" learning, involves not only those who engage directly with social movements, but also those who come in contact with movements through social media, campaigns posts, marches, demonstrations, or such other creative means as issue-based artworks, panel discussions, music, and theater.

It is against this background that I became involved with 15-to-18-year-old school-going youth activists engaging in climate action in the UK. Currently in the UK, youth-led climate movements are on the rise. Besides UKSCN, other popular ones include Extinction Rebellion Youth, Friends of the Earth, and Fridays for Future UK. These movements commonly use, for their activism, creative techniques that garner attention on a large scale, such as occupations of public spaces, mass mobilization marches, and silent demonstrations, as well as digital strikes, virtual events, and social media campaigns. For my study, I sought out the UK Student Climate Network (UKSCN), which is a movement comprising over 100 local groups and led entirely by students under age 22 . It seeks to put youth voices at the forefront of climate action. I chose UKSCN because of their focus on education reform, courtesy of their Teach the Future campaign, ${ }^{2}$ and for their broader intersectional focus on social issues in connection with climate change.

\section{The UK Student Climate Network, the Climate Crisis, and} Education

The UKSCN was set up on December 1, 2018, inspired by Greta Thunberg and the international Fridays for Future movement, and comprises young people 
under age 22. Its mission statement is to "stand for mass systematic change, putting diverse youth voices at the forefront of our campaign toward the UK Government, to ensure a liveable future for all". ${ }^{3}$ Intersectional in its approach, UKSCN believes that decarbonizing the economy and moving onto a path of sustainability entails working against all forms of oppression, including, but not limited to, racism, sexism, and transphobia, and it puts forward, correspondingly, that "climate justice cannot be reached without social justice!"4

Through its posts and campaigns, UKSCN clearly identifies itself as a dissenting organization, both in terms of where it chooses to organize and of the issues pertaining to climate change that it highlights. UKSCN organizes itself outside the hierarchical structure of schools and relies heavily on social media for its outreach, alongside physical protests. Moreover, the issues UKSCN engages with through its social media platforms and its recently launched (in April 2020) "Podcast for the Planet"5 demonstrate its activists' interest in intersectional discussions on the climate crisis. The key campaigns launched on UKSCN's social media since April 2020, for example, revolved around reforming the education system to address climate change and eco-anxiety (Teach the Future), climate justice as racial justice (in the context of the Black Lives Matter movement), defunding the police, and reducing the voting age to 16 , amongst others.

I found it interesting that across the UKSCN, education is seen as both the reason behind the climate crisis and as a solution to it. These juxtapositions are echoed in the episode on climate change education in a Teach the Future's podcast episode (UKSCN Podcast for Planet, 2020a). While pointing to the education system as "culpable for the mess we are in with regard to the climate crisis", the guest speaker recognizes education as "the pillar of our society .... So when it comes to finding solutions to an issue as monumental as climate change, the whole populace has to be educated" (UKSCN Podcast for Planet, 2020a). The activists see the education system as structurally flawed, one that merely seeks to build a future labor force for the market economy and is illequipped to engage learners critically with the complex issues in the world, particularly climate change:

Schools are simply not doing enough to enable young people to tackle multiple issues in our world, not just climate change .... Not only curriculum change is needed, but a whole reform of the education system itself - to be more focused upon creating mindful individuals who will go out and make the world a better place, rather than just getting them their qualifications and seeing them as numbers in the "marketization" system. (UKSCN Podcast for Planet, 2020a) 
Against this background, the next section explores the activists' experiences of climate change education in school.

\section{School Experiences of Climate Change Education}

\subsection{Climate Change Education in "Silos"}

During our interviews, youth activists described their encounters with climate change in school curricula as "negligible", "awful", restricted to "basic $\mathrm{CO}_{2}$ and weather stuff, revolving around how things work".

Honestly, it is awful. The whole school system is not focused on an actual issue. [Climate change] is something that is mentioned maybe in a chemistry class, and we will learn about how it works, but it's really basic, sort of as an aside - one page that you have to learn out of this whole big textbook. You don't really do much, and if you do talk about it, it's on the lines of, "How can we reduce plastic in the area? Recycle this and that". It's not going to change much in the grand scheme of things. (Personal communications, May and June 2020)

Even this limited amount of engagement with climate change vanishes in the final two years of secondary school for those students who decide to move away from natural sciences. Every research participant brought forward the issue of a "siloed" (compartmentalized) approach to climate change education in school, highlighting that their engagement with climate change is restricted to classes in geography and the natural sciences. Young people thus feel that the current education system, although it scratches the surface of the topic of climate change, leaves them to themselves to "connect the dots" as to its larger ecological and socioeconomic impacts. This view aligns with the argument put forth by Kwauk (2O2O, p. 14) that where the education sector incorporates ESD and climate change, it compartmentalizes them. It restricts them to climate science and thereby "creates a veil that obstructs our ability to see and to engage with issues of care, ethics, and equity that are inherent in climate change". As a result, without talking about the intersections with politics and power, the education system is unable to engage students with the issues of justice that arise with the climate crisis. In fact, in the natural sciences, participants stress, references to climate change are equally scarce and scattered. One participant recalls:

There were things in chemistry in the GCSE curriculum, on mapping the carbon emissions of an item, which got me thinking about the interconnected nature of items and their origin - how these impact humans 
and the society, which ones lead to increased carbon emissions later. But that was one lesson. The climate ecological breakdown is not addressed much. The education doesn't try to engage you with the issue. It's just there because it's part of the curriculum.

Another activist expressed frustration at schools' reluctance to recognize climate change as a "crisis", as to do so would signify the "tipping point where you start to recognize that things are going wrong which the current curriculum cannot yet tackle" (personal communication, May 30, 2020). Further vexations arise from the simplification even of issues that have explicit links to climate change, for example, energy sources. As an activist shared, "The debate between fossil fuels versus renewable energy sources is presented as a list of 'pros and cons', trying to make it a balanced argument, when it's not. We're past that. It's a crisis" (personal communication, May 30, 2020).

Youth activists I interviewed identified this simplistic, siloed, and sanitized formal type of education regarding climate change as a key motivating factor for their having undertaken climate activism. Young people are calling for their education to enable them to engage with complexities of the biggest existential threat to their generation and to recognize it for what it is: a global crisis. The question is whether the education system is prepared to rise to the challenge.

\section{2 "Commodification" of Learning}

The youth activists' perspectives during interviews and the nature of UKSCN's discourse on its social media make evident also that young people recognize themselves as "commodified". The education system treats them as a "commodity" needed by a future labor market and seeks to prepare them mainly for that role.

In secondary schools, the focus is on passing exams rather than preparing us for the future we face. In universities, our success is usually measured by our starting salary, not the social good we go on to achieve. This is compounded by the $£_{5} \circ, 000$ debt we graduate with, due to tuition fees, which incentivizes work that pays well over work that does good. (UKSCN Podcast for Planet, 2020a)

This speaker's description of the effect of the education system on student identity is representative of how students, despite their resistance, become "neoliberal subjects" (Keddie, 2016, p. 109). It reflects a "performative" and "entrepreneurial existence of calculation" (Keddie, 2016, p. 109), an existence that students are forced to lead because of the harsh standards against which they are judged, standards that flow from "targets", "indicators", and "norms". 
Keddie (2016) makes the case that students today are indeed "children of the market" because they live a "commodified" existence, both in their ability to achieve high measures of success within the education system and their ability to gain the skill sets that best help to contribute to the labor market in the future. Students feel the need to buy into competitiveness and emerge as "top performers" in the education system, because they know that competitiveness is valued over collaboration. They meet this state of affairs, however, not without anxiety or inner conflict, as underlined by Keddie (2016) and highlighted in an activist's words:

Our education system often teaches us to compete with our rivals and not to collaborate with our friends, and that itself is such a fundamental issue. How are we supposed to solve the issue [of climate change] that has been so lacklusterly passed down to us as a generation? There are much more important things going on in the world that we just do not know about, and we do not know how we can tackle them. Climate change is the perfect example. Schools simply are not doing enough to enable young people to tackle multiple issues in our world, not just climate change. (U KSCN Podcast for Planet, 2020a)

Their remarks make clear that young people see the pervasiveness of the neoliberal valuing of competition over collaboration as a hindrance to their engaging in meaningful climate change education. Thus, while young people continue to have agency to negotiate, accept, and reject neoliberal policies and practices, in reality they continue to be governed by them (Patrick, 2013). Learning within a system that has embraced neoliberal values - it puts producing "learning outputs" and "knowledge consumers" ahead of fulfilling learners' educational needs and desires - could lead to a sense of "isolation and helplessness" (p. 5) amongst learners and educators, as will be argued in the next section. However, the "commodified self" is an inevitable outcome of education, according to Patrick (2013), who reiterates that neoliberalism is a global agenda that underpins the educational strategy and policy that have given rise to the "knowledge economy". Despite common awareness of the particular impact of neoliberalism on education policy and practice, neoliberalism has achieved the status of "doxa" - "an unquestionable orthodoxy that operates as if it were the objective truth" (Patrick, 2013, p. 1).

Patrick (2013) says that students and educators need to struggle in their own ways against the "mundane, quotidian neoliberalisations" to create the possibility of thinking about education and themselves differently. In case of 
youth activists, the creation of alternate spaces through their activism can be seen as an act of resistance, a stand against conformity to the formal education system. The cry for collaboration and for tackling complex issues such as climate change in the education system represents students' resistance to "neoliberal governmentality", also called "the conduct of conduct". Other effects of such neoliberal education, particularly ESD, have been "individualization" and "responsibilization" of risk, which, I argue, are to be blamed for the many angsts, including eco-anxiety, that young people face. Such are the shortcomings of the education system.

\section{Eco-Anxiety and the Neoliberal "Responsibilization" and "Individualization" of Risk}

At first, I was involved in my school eco-group, but they were more into recycling and individual change, which, of course, is good, but I decided that I couldn't do that anymore. I couldn't just be doing the recycling and gardening when I was so freaked out by [climate change]. (Personal communication, May 24, 2020)

So says a youth activist who shared the reasons she undertook climate activism outside of school and with UKSCN. This research participant not only is disappointed in the limited engagement the curriculum offers her with regard to climate change, but she also struggles with institutional endorsements of such climate activism in the school environment as "eco-groups", which tend to be bound by the same structure of politics and power as classrooms are. Another participant also coped with her eco-anxiety by channeling it into activism with UKSCN. There she found a space to "process where the eco-anxiety is coming from and rationalize it, even if you can't get rid of it" (personal communication, May 26, 2020). UKSCN offers an opportunity for self-education on the ecological and policy dimensions of climate change as well as ally-ship (alliance) with others working toward a common goal.

Indeed, all five activists admitted to having personally experienced eco-anxiety. For one, eco-anxiety resembles a sense of "futility" in the face of a looming "global crisis" that is much larger than oneself (personal communication, May 30,2020 ). In this participant's experience, eco-anxiety can often act as a trigger if one is suffering from other mental health issues (personal communication, May 30, 2020). In particular, this participant asserted, the failure of the education system to prioritize students' mental health aggravates eco-anxiety: 
The education system is completely failing us with regard not only to climate change, but also to teen mental health. You sit for your exams no matter what. You have to revise and get the grades teachers are telling you. The system is already breaking you when you're 16. That's such an awful thing to grow up with. (Personal communication, May 30, 2020)

Kelly's (2001) ideas of "individualization" and "responsibilization" of risk onto youth relate to this discussion. It is evident that failures of the education system to meaningfully engage learners have led to increased feelings of anxiety amongst young people. In other words, failures of institutions and systems in power are passed onto young people subject to them, making the young people feel powerless and frustrated, burdened by "a sense of futility", in face of crises larger than themselves. Kelly (2001) takes the example of the "youthat-risk" notion that popularly ascribes "deviancy, delinquency, and deficit" to youth in general. Kelly warns against currents of thought that make pronouncements about youth identities - especially those that situate all youth as being at risk within "institutionalized risk environments" such as schools - viewpoints that thus pass on responsibility or "responsibilize" young people and their families for the young people's conduct and for their life trajectories (p. 25). This transfer of responsibility is apparent in the formal education system, which often minimizes the importance of the mental health of students and disclaims responsibility for it. Ojala's $(2012,2018)$ work on environmental awareness and education has been interesting in this regard. It speaks of young people's "de-emphasizing" the issue of climate change. Ojala (2018, p. 12) speculates why:

This response - de-emphasizing - could be due to the fact that they do not value environmental issues that highly, and therefore do not consider climate change to be a serious threat. It could be because some embrace worldviews, values and lifestyles that are threatened by the societal changes that adapting to the reality of climate change would imply.

The ideas expressed in youth-led climate activism generally and my personal interactions with young activists demonstrate the complete opposite. Young people are not only concerned about climate change, but also do not desire "simplification" of an issue that they deem an existential threat, as elaborated upon in the previous section. Through their activism, they critique the inaction not only of policymakers but also of the education system. I argue, therefore, that a "deficit discourse" (one that defines people by their deficiencies) premised on young people's lack of awareness or lack of enthusiasm with 
regard to environmental issues in a time of a global climate crisis is unconstructive. It may lead to a simplistic "awareness raising" educational curriculum, as opposed to the meaningful engagement that young people are calling for.

The UKSCN includes demands that any learning pathways for students and teacher trainings around climate change education must address "the very real problem of eco-anxiety" amongst young people (UKSCN, 2O2O, p. 4), all the while addressing the need for appropriate teacher training in this regard.

\section{An Intersectional Struggle for Climate Justice}

Climate justice is a predominant theme across UKSCN social media, open calls, and interviews. And the different ways young people understand and engage with ideas of climate justice reflect the complexity of the climate movement. Scandrett (2016) says that the degree of contestation that marks notions of climate justice reflects the material interests of the divers and diverse social groups that have access to the process of controlling the analysis in this field of inquiry. At its best, climate justice is rooted in a common battle against the hydrocarbon economy, against "an economic logic of growth and capital accumulation" (Scandrett, 2016, p. 477). In policy-oriented circles, climate justice tends to be understood as redistributive and as a moral issue, as exemplified by the language of the Mary Robinson Foundation (2015): "Climate justice links human rights and development to achieve a human-centred approach, safeguarding the rights of the most vulnerable and sharing the burdens and benefits of climate change and its resolution equitably and fairly". The global justice movement, on the other hand, views climate change as a social justice issue, seeks to amplify voices of those directly affected by climate change, and it questions authority structures.

Against this background, I conclude that young people navigate ideas of climate justice differently inside and outside classrooms. In fact, the lack of opportunities to dabble in issues of climate (in)justice in education has been paramount in determining how climate activism takes shape in UKSCN. According to activists, the Eurocentric nature of the UK school curriculum does not leave room to discuss the justice issues related to climate change:

Especially in Britain, there is a very Eurocentric curriculum. People of color are more affected by climate change. We should be taught how it affects people differently and not how to drown out the voices. I don't like the idea of people just going into somewhere and saying, "I will give you a solution to your issue". 
To counteract Eurocentrism, activists say, they try in the UKSCN community to adopt more of a "global outlook" to climate change. The idea of a global citizenship does not take shape inside classrooms, even though it's embedded in the UN Sustainable Development Goal 4.7 (UNESCO, 2016), but rather outside the classroom. It happens in the kind of activist context that affords young people the space to "go beyond the UK" as well as to express their opposition to the UK's current protectionist policies, as expressed here:

It's also being part of a global community that's important, which Britain isn't generally very good at. In UKSCN we have this idea of a global community, not just reparations for colonialism. We're aware of being a powerful country. We can't criticize other people's emissions until we've sorted ourselves out. Yet we can't just focus on what's going to happen to us when things affecting our global community are ultimately going to affect us.

In classrooms, struggles over the meaning of climate justice are bound by the parameters of the school curriculum. These struggles occur more profoundly in activist spaces, where various justice issues get linked, solidarities form, and "intersectional activism" ${ }^{6}$ is put into practice. The UKSCN mission statement underlines intersectionality: it equates climate justice with social justice. UKSCN activists cut across the kind of siloed approach to climate change found in arenas of education, science, and policy. Instead, they highlight the interlinkages among various social justice issues. By drawing connections between social issues, young people form solidarities and come together to create a bigger movement.

A point that deserves to be noted by the global education community is that while climate justice remains unaddressed in school climate change education, young people want to engage with it, and they have demonstrated as much through the form of climate activism they espouse. Their activism is an act of "disruptive dissent" (O'Brien et al., 2018), in opposition to simplistic and siloed climate education, to a neoliberal model of education that individualizes structural issues, and to oppressive structures of power.

I can give three specific examples of intersectional activism. First, against the background of the Black Lives Matter movement protests to demand justice for the killing of George Floyd in police custody on May 25, 2020, in Minneapolis, United States, UKSCN actively campaigned for racial justice over its digital media. It also released a podcast episode discussing racism in the climate movement and strategies for anti-racism and ally-ship (UKSCN Podcast 
for Planet, 202ob). Figure 8.2, which captures the campaign posts on Instagram, demonstrates how UKSCN chose to connect climate justice with racial justice:

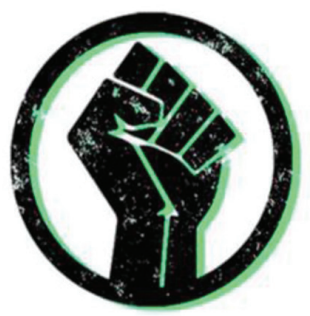

WHY GLIMATE JUSTIGE IS ANTI-RACIST: IN SOLIDARITY WITH BLACK LIVES MATTER

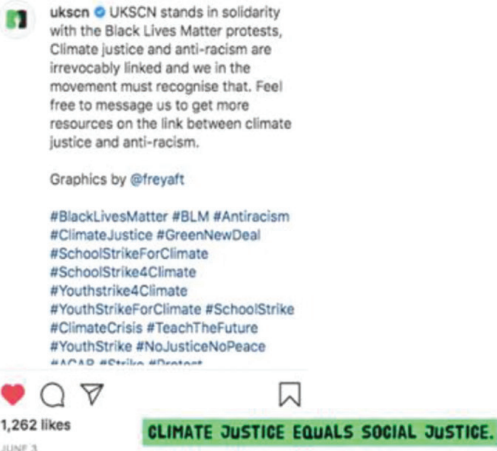

UKSCN GIVES OUR FULL SOLIDARITY TO THOSE FIGHTING AGAINST RACIST POLICING ACROSS THE WORLD.

RACISM AND CLIMATE CHANGE ARE FUNDAMENTALLY CONNECTED. THE CLIMATE CRISIS IS BOTH CAUSED BY AND ENTRENCHING OUR WORLD'S RACIST, IMPERIALIST SYSTEMS.

\section{IF THE CLIMATE JUSTICE MOVEMENT DECIDES TO IGNORE RACISM, WE HAVE BECOME THE OPPRESSOR. IT IS OUR DUTY TO ACT.}

UNTIL WE ACHIEVE FULL JUSTICE, THERE WILL BE NO PEACE.

MESSAGE US FOR RESOURCES ABOUT ANTI-RAEISM ANO CLIMATE JUSTIEE

FIGURE 8.2 UKSCN advocacy on racial justice. Collage of images captured from Instagram posts by UKSCN on June 3, 2020, and June 5, 2020; https://www.instagram.com/ $\mathrm{ukscn} /$ ?hl=en

Second, UKSCN's next campaign revolved around defunding the police. It again chose an intersectional approach, highlighting that police brutality is generally targeted at the same marginalized groups that are disproportionately affected by climate change.

In the third example, USKCN activists exhibited what Ojala (2012) calls "constructive hope" in deciding to advocate for a Green New Deal (GND). ${ }^{7}$ With regard to this example, I argue that the youth activists' optimism about the potential of the GND indicates "problem-focused coping" and a trust in other actors (Ojala, 2012, p. 636). I find the notion of constructive hope instructive in unraveling the optimism around the GND. The following paragraphs exemplify how youth activists again employ an intersectional approach, seeing the GND 


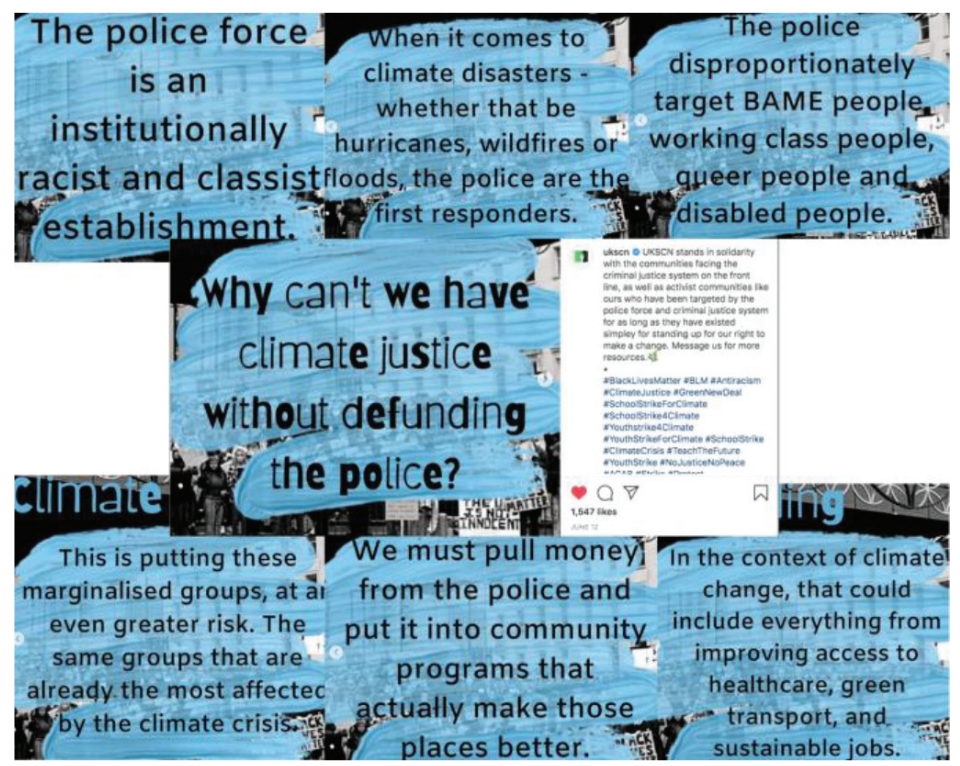

FIGURE 8.3 UKSCN campaign on defunding the police. U KSCN's Instagram page, June 12, 2020, https://www.instagram.com/p/CBVXx7THp--/

as a tool for climate justice. It is the idea that the GND can deliver climate and social justice - by decarbonizing the economy, creating sustainable or green jobs for all workers, and reducing income and social inequalities - that appeals to young people. The implementation of the GND, for young people, would imply a triumph for climate justice.

The activists' narrative supports that of Paul (2O2O), who advocates that the Green New Deal be intricately tied with the global justice movement, that it recognizes the historic legacies of colonialism and fossil capitalism. Paul's idea that "only a globally equitable transition will be a truly resilient transition" (2020, p. 69) is mirrored in one youth interviewee's comment:

The other thing with the Green New Deal is that it addresses the inequality and equity, and the historical background for that. It has an international outlook.

In encompassing the idea of "green" jobs, the GND envisions a shift in the market economy as to which skill sets are "valued"(Mazzucato, 2018). Youth activists envisage an economy with social justice and equity at its core. They harbor a hope that the GND will appreciate the value of people's varied skill sets and build a "social" economy, which would in turn invest in vocational education: 
There's quite a big investment in solar panels in the southwest in Cornwall, one of the most deprived areas in the south. Electricians or electric plumbers would go and take an extra course in how to fit a solar panel. It's about training and developing kinds of solutions.

Constructing hope around the GND also serves to tame eco-anxiety. One activist underlined her hope that debates around the GND and policy reform would find a place in education:

I think the cure to eco-anxiety, in a sense, is education: understanding what's going on and understanding ways that are being made to make it better. At first, I was freaking out [that I was] going about creating these emissions. But if we have that kind of education about a Green New Deal and about policy reform - these are things that can make it better. [Education] can help you make a more informed decision on how you're voting and how you're interacting with politics in the country. It helps you, not to get rid of eco-anxiety, but to understand where it's coming from.

This section thus illustrates how the various platforms created within UKSCN enable young people to engage in critical thinking about intersectionality among various complex justice issues - the climate crisis, racial discrimination, police, and policy reforms. Having a space to navigate and exchange their ideas, doubts, and emotions also enables young people to cope with eco-anxiety. The intersectionality in youth climate activism is a cry for intersectionality in all climate education. In the concluding section, I advocate for a similar intersectional approach to thinking about climate change across the board in education policy, practice, and research. and Practice

In order that education policy and practice result in an education that goes beyond simplistic awareness-raising, the issue of the breaking of silos in climate change education needs to be addressed. Referencing Kwauk's first roadblock (Kwauk, 2020), I explore several ways to move toward "radical" and "transformative" climate change education, as is also envisaged by UN SDG 4.7, which shapes the UK's ESD framework (UNESCO, 2013). I draw from youth activists' perspectives to develop these implications. 

Change

Currently, the linkages among various aspects featured in SDG Target 4.7 ESD, global citizenship, gender equality, and human rights - have yet to contribute to the global goals of quality education (Kwauk, 2020). Climate change education needs to move toward addressing climate change as a multifaceted problem that cannot be compartmentalized into natural sciences and geography and simply leave students on their own to create any "big picture" around climate change. The challenge also includes dismantling the largely STEM ("science, technology, engineering, mathematics") focus of climate change, because it is the "hegemonic articulation that seeks to normalize a neoliberal 'common sense' about these [STEM] disciplinary fields" (Sharma, 2016, p. 47).

Lehtonen et al. (2019) further echo the dangers of compartmentalized climate education: "While subject-oriented learning could give learners a multidimensional picture of a 'wicked global problem', the fragmented knowledge will restrict learners from creating linkages across domains and disciplines to obtain a 'full picture" (p. 361). Since "the perception of the problem frames the solutions" (Lehtonen et al., 2019, p. 341), education needs to afford greater attention to the "roots" of climate change, including human-nature interconnections, individualism, and consumerism. Education also needs to address climate denial, climate ethics, and dichotomies that dominate modern day thinking (global-local, subject-object, mind-body) and move toward understanding interconnectedness (pp. 344-345). The implication is that education moves away from subject-oriented silos to "phenomena-based learning", which involves a systemic approach to a multi-dimensional problem such as climate change and which is guided by learners' questions via a pedagogy that encourages learning by means of embodied and shared experiences (Lehtonen et al., 2019).

Curriculum subject areas could, however, host dedicated modules on climate change that could contribute to presenting the "big picture". Youth activists, in fact, identified various entry points in the school curriculum that could entertain a form of phenomena-based learning. Food technology, for example, could engage learners in constructive discussions about food choices and about the rise of veganism and vegetarianism in response to the climate crisis. A research participant pointed out that learning about climate change as early as possible would not only help with eco-anxiety but also equip learners to think about steps they can take from an early age. Primary school students could, for example, develop a nurturing relationship with nature with such "hands-on" projects as learning how to garden in small spaces and cooking plant-based food. 
Environmental education as a curriculum subject could also more centrally discuss the history of environmental activism around the world. As a research participant emphasized,

Fridays for Future did not invent climate protests. This is not something new, and we shouldn't teach it as such. We need to know more about environmental activism historically in Indigenous communities and in the Global South.

Further, climate change education needs to be international yet sensitive to context and respectful of the diversity of communities. Youth activists underscored the need to address Eurocentrism and the deficit discourse around the "Global South":

In geography lessons, if we did on the odd chance learn about some sort of climate change, it was always in the Global South. Like, "Oh, look at all the poor conditions these poor people are living in". A typical white Westerner looking on the rest of the world in a superior way. I remember thinking, "Why have we taken this very hierarchical standpoint on other countries?"

\subsection{Teacher Education}

For tackling eco-anxiety amongst adolescents and young adults, Ojala (2018), in addition to endorsing other approaches, highlights the role of educational institutions in creating spaces where young people can critically engage their minds regarding dilemmas and the anxiety of upcoming adulthood, while also being able to "challenge tendencies towards black-and-white thinking by presenting alternative, more constructive, ways of dealing with ambivalence" (p. 15). So far, self-created activist platforms fill these needs. To re-create their equivalent in schools, training of educationists and schoolteachers in leading such spaces is also paramount. Kwauk (2020) ascribes to teacher education a vital role in creating an "enabling environment through which ESD is translated into the classroom" (p. 16). In agreement, UKSCN has demanded that the UK Government, following the example of Scotland, mandate that teacher training programs institute modules on climate emergency and ecological crisis (UKSCN, 2020, p. 4).

In a survey of $35^{\circ}$ primary and secondary school teachers across the UK, $69 \%$ of teachers said that there should be more teaching about climate change in UK schools, although $75 \%$ did not feel adequately trained to do so (UKSCN, 2020). This feeling is typified by schoolteacher Laura Tsabet (2020) 
whose experience of eco-anxiety led her to self-educate about climate change through a UN accredited course with EduCCate Global ${ }^{8}$ so that she could better engage with her students. Indeed, much like the youth activists, she found that locating a global community of teachers was helpful in coping with her anxiety while also "effecting change through education" (para. 15).

Teacher education on climate change would also further recognition of "points of entry" for phenomena-based learning on climate change. As schoolteacher Philip Bell (2019) muses, "How often do students study climate poetry, or learn about entropy in economics?” (para. 8).

\subsection{Connecting the Dots: Climate Justice in Education}

Key to constructing the big picture on climate change in education is acknowledging the social, cultural, and political impacts of climate change on communities. Climate justice therefore needs to become an integral part of climate change education. Youth activists identified that climate justice is not a "stand alone" topic. Deeply tied to social injustices, climate justice could be engaged within a range of compulsory subjects in school curricula. In implementing such a measure, interdisciplinary and transdisciplinary approaches would be invaluable, providing a welcome intersectionality.

Kaijser and Kronsell (2014) highlight that an intersectional approach to addressing climate justice would illuminate "how different individuals and groups relate differently to climate change, due to their situatedness in power structures based on context-specific and dynamic social categorisations" (p. 417). A research participant similarly spoke of a need for intersectionality in climate change education:

Having knowledge from different subjects about the science behind climate change and also the injustice from the history - we can bring that all together into some kind of climate justice education. You can't really understand the intersectionality of issues unless you have the foundations for it, which currently just aren't being taught.

In thinking about phenomena-based learning and climate justice, our youth activists saw history lessons as the ideal place "to understand the power webs where social and natural aspects are entangled" (Kaijser \& Kronsell, 2014, p. 424). They also stressed the tactical roles that subjects such as religious studies, philosophy, and ethics could play in learning about climate justice:

You could talk about climate justice from an ethical standpoint. This could be around the sanctity of life (human rights) and the sanctity of 
nature. Philosophy-and-ethics as a subject focuses a lot on how you balance right and wrong, and how that interrelates with religions; so you could easily link that to climate change and the need for conservation, or discussing why deforestation is bad. It could get people thinking about the same topic in different ways.

In conclusion, the consensus among the youth activists was that a climate justice education would enable learners to finally "connect the dots". It would be "an active attempt at understanding climate change, colonialism, and injustice, and then at linking that to the effects of rising emissions and energy production". The key to a critical and transformative climate change education is thus, as contemplated by Henderson (2019), "Teach climate change as if power matters" (p. 987).

In Closing

In summary, the alternative institutions that youth activists have built through their activism deserve to be recognized as sites of learning, developing knowledge, building skills, and building networks.

On June 29, 2020, after a series of digital strikes by Teach the Future's Green Recovery for Education campaign and an open letter to Chancellor of the Exchequer Rishi Sunak with 1,105 student signatures, the UK government announced plans to invest over $£ 1$ billion in a ten-year school rebuilding and retrofitting program. ${ }^{9}$

Keeping such successes in mind, future ESD and climate change education research would also benefit greatly from a focus on youth-led climate activism and from closer collaboration with such activism. And, as argued by Cutter-Mackenzie and Rousell (2019), for truly transformative climate change education, such collaborations must center on the voices of young people and, in fact, enable young people to be at the forefront of such research. As aspired to by Eaton and Day (2O2O), "environmental education must begin building a counter-hegemony that would produce citizens capable of understanding and fighting for a different world" (p. 471).

\section{Notes}

1 Read more about AYcc's initiative here: https://www.switchedonschools.org.au/about

2 Read more about UKSCN's Teach the Future here: https://www.teachthefuture.uk/ 
3 See UKsCN "About Us": https://ukscn.org/about-us/

4 See UKSCN "About Us": https://ukscn.org/about-us/

5 UKSCN's Podcast for the Planet: https://open.spotify.com/show/1sWI2VyeGcSIxIAHBAFaAK

6 The term "intersectional" in this section implies a way of thinking about the junction of various issues. The term relates closely to the term "crosscutting" in this regard. Unless otherwise specified, it is not meant as a reference to intersectionality as a theory that was developed by Kimberlé Crenshaw (1989).

7 Popularly seen as an alternative to modern neoliberal capitalism, the Green New Deal questions core values around which the economy and state are organized (Harcourt, 2014). Calling for a "new initiative for economic and environmental transformation", the Green New Deal questions growth as the main focus of economic policies and offers in its place re-regulation of finance and taxation, significant government investment in renewable resources, and training a "carbon army" of low- and high-skilled workers for emerging "green collar" jobs (Harcourt, 2014; Simms et al., 2008).

8 The EduCCate Global website: https://www.educcateglobal.org/

9 Read the full statement and press release by UKSCN here: teachthefuture.uk/post/ investment-announcement

\section{References}

Bell, P. (2019, December 15). Why isn't climate change at the centre of curricula? Tes. https://www.tes.com/news/why-isnt-climate-change-centre-curricula

Bonnett, M. (1999). Education for sustainable development: A coherent philosophy for environmental education? Cambridge Journal of Education, 29(3), 313-324. doi:10.1080.0305764990290302

Byrne, E. P., \& Mullally, G. (2016). Seeing beyond silos: Transdisciplinary approaches to education as a means of addressing sustainability issues. In W. Leal Filho \& S. Nesbit (Eds.), New developments in engineering education for sustainable development (pp. 23-34). Springer. doi:10.1007.978-3-319-32933-8_3

Choudry, A. (2015). Epilogue: Lessons from activist learning, education, and research. In A. Choudry (Ed.), Learning activism: The intellectual life of contemporary social movements. University of Toronto Press. http://ebookcentral.proquest.com/lib/ cam/detail.action?docID $=4931342$

Clover, D. E., \& Hall, B. L. (2012). Critique, create, and act: Environmental adult and social movement learning in an era of climate change. In F. Kagawa \& D. Selby (Eds.), Education and climate change: Living and learning in interesting times (pp. 161-174). Routledge.

Crenshaw, K. (1989). Demarginalizing the intersection of race and sex: A black feminist critique of antidiscrimination doctrine, feminist theory and antiracist politics. University of Chicago Legal Forum, 1989(1), 31.

Cutter-Mackenzie, A., \& Rousell, D. (2019). Education for what? Shaping the field of climate change education with children and young people as co-researchers. Children's Geographies, 17(1), 90-104. doi:10.1080.14733285.2018.1467556 
Davies, I., Evans, M., \& Peterson, A. (Eds.). (2014). Civic activism, engagement and education: Issues and trends. Journal of Social Science Education, 13(4), 2-10. https://www.jsse.org/index.php/jsse/article/view/719/778

Eaton, E. M., \& Day, N. A. (2020). Petro-pedagogy: Fossil fuel interests and the obstruction of climate justice in public education. Environmental Education Research, 26(4), 457-473. doi:10.1080.13504622.2019.1650164

Fisher, S. R. (2016). Life trajectories of youth committing to climate activism. Environmental Education Research, 22(2), 229-247. doi:10.1080.13504622.2015.1007337

Germanos, A. (2019, December 12). Youth climate activists storm COP25 stage. EcoWatch. https://www.ecowatch.com/cop25-youth-climate-activists-2641580292.html

González-Gaudiano, E. (2005). Education for sustainable development: Configuration and meaning. Policy Futures in Education, 3(3), 243-250. doi:10.2304.pfie.2005·3·3.2

Henderson, J. A. (2019). Learning to teach climate change as if power matters. Environmental Education Research, 25(6), 987-99o. doi:10.1080.13504622.2019.1660309

Ho, E. (2010). Children's ideas about climate change. Library and Archives Canada.

Holmberg, A., \& Alvinius, A. (2020). Children's protest in relation to the climate emergency: A qualitative study on a new form of resistance promoting political and social change. Childhood, 27(1), 78-92. doi:10.1177.0907568219879970

Huckle, J., \& Wals, A. E. J. (2015). The UN decade of education for sustainable development: Business as usual in the end. Environmental Education Research, 21(3), 491505. doi:10.1080.13504622.2015.1011084

Jucker, R. (2004). Have the cake and eat it: Ecojustice versus development? Is it possible to reconcile social and economic equity, ecological sustainability, and human development? Some implications for ecojustice education. Educational Studies, 36(1), 10-26. doi:10.1207.s15326993es36o1_3

Kaijser, A., \& Kronsell, A. (2014). Climate change through the lens of intersectionality. Environmental Politics, 23(3), 417-433. doi:10.1080.o9644016.2013.835203

Keddie, A. (2016). Children of the market: Performativity, neoliberal responsibilisation and the construction of student identities. Oxford Review of Education, 42(1), 108122. doi:10.1080.03054985.2016.1142865

Kelly, P. (2001). Youth at risk: Processes of individualisation and responsibilisation in the risk society. Discourse: Studies in the Cultural Politics of Education, 22(1), 23-33. https://doi.org/10.1080/01596300120039731

Kwauk, C. (2020). Roadmaps to quality education in a time of climate change. Brookings. https://www.brookings.edu/research/roadblocks-to-quality-education-in-a-timeof-climate-change/

Lehtonen, A., Salonen, A. O., \& Cantell, H. (2019). Climate change education: A new approach for a world of wicked problems. In J. W. Cook (Ed.), Sustainability, human well-being, and the future of education (pp. 339-374). Springer. https://doi.org/ 10.1007/978-3-319-78580-6_11 
Mary Robinson Foundation. (2015). Principles of climate justice. www.mrfcj.org/about/ principles.htmla

Mazzucato, M. (2018). The value of everything: Making and taking in the global economy. Penguin.

O'Brien, K., Selboe, E., \& Hayward, B. (2018). Exploring youth activism on climate change: Dutiful, disruptive, and dangerous dissent. Ecology and Society, 23(3). https://doi.org/10.5751/ES-10287-230342

Ojala, M. (2012). Hope and climate change: The importance of hope for environmental engagement among young people. Environmental Education Research, 18(5), 625642. https://doi.org/10.1080/13504622.2011.637157

Ojala, M. (2018). Eco-anxiety. RSA Journal, 164(4), 10-15. https://www.jstor.org/stable/ 26798430

Patrick, F. (2013, April 23). Neoliberalism, the knowledge economy, and the learner: Challenging the inevitability of the commodified self as an outcome of education. ISRN Education. https://doi.org/10.1155/2013/108705

Paul, H. K. (2020). The Green New Deal and global justice. Renewal: AJournal of Labour Politics, 28(1), 61-71.

Scandrett, E. (2016). Climate justice: Contested discourse and social transformation. International Journal of Climate Change Strategies and Management, 8(4), 477-487. http://doi.org/10.1108/IJCCSM-o5-2015-0o6o

Selby, D., \& Kagawa, F. (2010). Runaway climate change as challenge to the 'closing circle' of education for sustainable development. Journal of Education for Sustainable Development, 4(1), 37-5o. https://doi.org/10.1177/o97340820900400111

Sharma, R. (2020). Interrogating equity within education for sustainable development. Cambridge Educational Research E-Journal, 7, 35-52. https://doi.org/10.17863/ CAM. 58326

Sukarieh, M., Tannock, S., \& Tannock, S. (2014). Youth rising? The politics of youth in the global economy. Routledge. https://doi.org/10.4324/978131588466o

Tsabet, L. (2020, January 5). How (and why) I became a climate change teacher. Tes. https://www.tes.com/news/how-and-why-i-became-climate-change-teacher

UKSCN [UK Student Climate Network]. (2020). About us. UKSCN. https://ukscn.org/ about-us/

UKSCN Podcast for Planet. (2O2Oa, April 10). The importance of climate education. https://open.spotify.com/episode/1nybuk6AtiCqN72Pfj6Sq3

UKSCN Podcast for Planet. (2O2Ob, June 5). Anti-racism and climate justice. https://open.spotify.com/show/1sWI2VyeGcSIxIAHBAFaAK

UNESCO. (2016, September 6). What is education for sustainable development? https://en.unesco.org/themes/education-sustainable-development/what-is-esd 